\title{
The Extent to Which Mobile Learning is Employed in the Educational Process in Jordanian Government Schools from the Teachers' Perspective
}

\author{
Dr. Muneera abd alkareem shdefat \\ The Ministry of Education, Jordan
}

\begin{abstract}
The study aimed to identify the extent of mobile learning employment in the educational process in Jordanian government schools from the teachers' perspective. To achieve the aim of the study, the descriptive approach was utilized where a questionnaire consisting of three domains (cognition, skill, and evaluation) was developed with (20) paragraphs. The paragraphs validity and reliability were established, then the questionnaire was distributed to the study sample that consisted of (360) teachers in Jordanian government schools. The results of the study showed that the extent of mobile learning employment in the educational process from the perspective of Jordanian government school teachers appeared with a low degree, with an arithmetic mean of (1.79). The results further showed a statistically significant difference in the evaluations of the study sample individuals for the authenticity of employing mobile learning in the educational process according to the perspective of Jordanian government school teachers according to the gender and attributed to the males, and on all dimensions, in addition to the presence of statistically significant differences according to the educational qualification and attributed to higher studies, at the macro level of the tool and on the cognition and skill domains.In light of the study results, the researcher recommended that the Ministry of Education should offer more specialized training courses and workshops in the field of teaching technology and mobile learning and recommend teachers to apply them in the educational process. Furthermore, it is required to spread awareness among teachers and students about the advantages of utilizing mobile learning and modern technology in learning.
\end{abstract}

Keywords: mobile learning, educational process.

DOI: $10.7176 /$ RHSS/10-12-07

Publication date:June 30th 2020

\section{Introduction}

The current century has witnessed many changes in all areas of life. The most prominent of which is the technological area that has developed tremendously, the before-mentioned included cell phones, computers, and the Internet. These advancements were accompanied by a group of recent improvements and brand-new challenges and resulted in the disappearance of spatial and temporal barriers which provided a fast and effective communication through the role of information technology in the flow of information and news and facilitating the process of communication. The cell phone is regarded as one of the latest and best technological innovations because it has become a source of knowledge, a carrier of culture, and a tool for communication through the Internet and social networks.

Due to the fact that the educational institutions are social organizations that play a leading role and maintain a great responsibility in achieving intellectual capital advancement, technological progress, development of the knowledge economy, and sustaining a balance between preserving self-identity and fitting in the global community.

Education, throughout this developing world, is witnessing massive changes and transformations as a result of contemporary information technology, and civilization advancements, in addition to utilizing them in the most suitable means. Conceivably, this outlines the genuine challenge for the educational institutions in the less developed societies in particular. On the contrary, the developed societies have taken the grounds for the development and worked to keep pace with these modern developments in a way that serves their interests and achieves their desired goals (Bizan, 2015).

These advancements have produced the Technology of Education and mobile learning that has attracted a lot of attention and promoted many transformations, and they are among the recently most utilized technologies due to their advantages, spread, and interaction. They provide a rich educational environment, multiple sources, and encourage communication between the educational system constituents. They provide modeling of education and present it in a standardized form. They support preparing a generation of teachers and learners who are capable of handling technology while being equipped with the latest skills of the age (Abu Al-Majd, 2014).

As a consequence of the emergence of the technology of education, distance education, and mobile learning, the role of the teacher has changed in a clear way to express his/her new tasks, and the role of the learner has changed. The learner is no longer a passive recipient, as it demanded that he/she become dynamic and interactive during the educational situation moreover the learner is required to self evaluate. The curricula's content, activities, 
presentation methods, and methods of evaluation have been affected. Providing the students with the skills of selfeducation, individualization of education, mastery, and equal opportunities has become the first criterion for the educational systems. (Al-Baghdadi, 2015).

Mobile learning is considered a form of distance learning and the expansion of e-learning. The word (mobile) means portable. Mobile learning is defined as the use of mobile or wireless devices in the process of teaching and learning to equip students with cognitive skills in addition to other skills through response and interaction (AlOmari, 2011).

Al-Azzam (2017) pointed out that the increasing usage of mobile phones throughout the world is one of many factors and reasons for the request to benefit from mobile devices in education. At the present time, mobile phones have become one of the technological tools that hardly depart their users, and the number of these users has increased significantly, since these devices have become inexpensive, and they offer various services in the field of education and learning. These mobile phones are characterized by their high ability in reaching individuals anywhere and at any time, in a way that supports its encompassing groups of diverse ages with varied characteristics. These devices are able to store a large amount of information or books, summaries, and reviews necessary for the teaching and learning process. Furthermore, they make learning more enjoyable by combining the processes of learning and playing, in addition to the innovation and vitality in the learning process through the use of audio and video services. Mobile phones provide us with lifelong learning. The prevalence and spread of methods and patterns of Distance Education have related to the societies need for this kind of education to help overcome the obstacles of traditional education such as the lack of financial resources that provide proper university education in light of the high cost of this type, as well as the shrinking of traditional sources of funding and the lack of alternative sources that meet the needs for large sectors of society or some groups of students who do not meet the traditional admission requirements at the present and future time.

Given the importance of the educational process as one of the most essential pillars that society adopts for its advancement, growth, and prosperity and the building of its values and ideas, the educational process must be taken care of by upgrading its means and supporting it to achieve its goals. The use of mobile phones in the educational process has become an essential and vital issue to expand knowledge, and keep pace with the development taking place in the developed countries. Investment in education is one of the most significant fields of investment that affects society. Therefore, this study came to reveal the importance of employing mobile learning in the educational process in Jordanian government schools because school students constitute the basic building block that the Jordanian community builds on. These students have inherent powers and a tremendous ability to obtain individual cognitive acquisition and future thinking skills, and they are the most vulnerable group.

\subsection{The Problem of the Study}

Education is witnessing rapid changes and transformations as a consequence of the present technological and information revolution, and the means to implement this change to enhance the educational process represent a real challenge for educational institutions particularly in the less developed societies.

The technological revolution has become a prominent application in the current century, and this requires that traditional education administrators should replace their systems with other systems that are more open and can keep pace with the rapid changes in technology, in addition to being compatible with the manner the new generation functions with the Internet. The Internet imposed itself and transferred learning from a wired learning environment that uses a computer to a new wireless learning environment that utilizes mobile phones. (Bizan, 2015)

The Internet is implemented in the educational process with all its applications for training and practice, obtaining various educational programs, and receiving the latest findings of science in various areas of knowledge. Furthermore, Students can share their work and publish their writings, researches, and perspectives individually or collectively (Ahmed, 2011).

Given this increasing mobile phone utilization and spread in society in general, and among young people in particular, and due to the importance of the educational process, the employment of mobile learning in the educational process might generate effective education if exercised properly and effectively. This will produce a rich educational environment, provide multiple sources, and allow modeling and present education in a standardized form. It likewise prepares a generation of teachers and learners armed with the latest skills of the time and ready to deal with information technology communication.

Throughout the work of the researcher as a school principal in the Ministry of Education, and her perception of the lack of employment of mobile learning in the educational process in Jordanian government schools, the researcher has decided that the problem of the study is determined in the following main question: What is the extent of employment of mobile learning in the educational process in Jordanian government schools?

\subsubsection{Study Objective and Questions}

The study aimed to identify the extent of employment of mobile learning in the educational process in Jordanian 
government schools by answering the following questions:

The first question: What is the extent of employment of mobile learning in the educational process in Jordanian government schools from the teachers' perspective?

The second question: Are there any statistically significant differences at the level $(\alpha=0.05)$ in the study sample estimates for the extent of employment of mobile learning in the educational process in Jordanian government schools according to the gender and educational qualification variables?

\subsubsection{The Importance of the Study}

The importance of this study arises from the impact achieved by the widespread of mobile phones, which gave mobile phones a distinguished presence among those in charge of educational institutions as an effective educational tool if used properly.

It is expected that the following will benefit from the study results:

1- The Ministry of Education, through its endeavor to obtain the most recent findings of science in various fields of knowledge to employ them in the Ministry.

2- Teachers, as this study establishes a starting point for teachers to employ mobile phones in the educational process away from indoctrination, and communicate the scientific material properly and more interestingly.

4- This study is expected to validate the importance of mobile learning in the educational process to the educational experts.

5- This study is expected to provide the Arab library with a theoretical framework for mobile learning.

6- Researchers, as this study sets an information base and a significant spot for conducting other studies and research on the subject of the study.

\subsubsection{Limits of the Study:}

The limitations of the study are determined as follows:

Topic limits: The extent to which mobile learning is employed in the educational process in Jordanian government schools.

Sample size/sample bias: The study was limited to a sample of male and female teachers in government schools in the Jordanian Ministry of Education.

Time limits: The study was implemented during the academic year 2018/2019.

Spatial limits: The study was applied in government schools in the Jordanian Ministry of Education.

\subsubsection{The Terminology of the Study:}

The study adopts the following terms:

Mobile Learning:

Al-Hamid $(12,2013)$ defined it as: "A modern form of learning emerged as a result of the development and widespread of e-learning, this form of learning is mainly dependent on the use of mobile wireless devices (mobile phones, smart phones, digital aids ...) that help the learner to independently learn on his own space, pace, and time".

As for the procedural definition, the study adopts the concept of mobile learning as the type of learning in which learners use mobile phones and benefit from the wireless communication on the internet that grants them access to the scientific material in any place and anytime.

Educational Process:

Sahel defines it $(2014,65)$ as: "The procedures and activities that take place in the classroom, and aim to provide learners with theoretical knowledge, practical skills or positive attitudes. It is a knowledge system consisting of inputs, processing, and outputs. The input is the learner. The processing is the coordination process for organizing, understanding, interpreting knowledge, and forming a relationship between this knowledge and associating it with previous knowledge. As for the output, it is represented in the graduation of competent, educated students.

As for the procedural definition, the study adopts the idiomatic concept as a procedural concept.

\subsubsection{Previous Studies:}

Several studies that are partly related to this study were classified according to a chronological order from oldest to most recent then introduced and presented as follows:

Al-Shahat (2014) conducted a study that aimed at proposing a model for employing mobile learning in educational situations and its effectiveness on students of intermediate level in Qaliubiya governorate. The researcher used the descriptive approach in analyzing studies and the semi-experimental approach in applying the proposed model on an intentional sample consisting of (60) students, the sample was divided into two groups, a control group consisting of (30) pupils taught in the traditional fashion, and an experimental group of (30) pupils on whom pre and post measurements were applied, and this group was taught by the mobile learning model. The results of the study showed that there are statistically significant differences in favor of the experimental group in a cognitive 
achievement test. Furthermore, the results revealed that the views and responses of students in the experimental group were all at very high levels which confirm that the mobile learning model is highly effective in influencing positively on achieving the goals of the emotional side of the experimental group students.

Shams El-Din (2016) conducted a study aimed to identify the effect of using some mobile education applications on developing the technical literacy of home economics teachers and their attitudes towards mobile education in Menoufia Governorate in Algeria. The researcher adopted the descriptive analytical approach to apply its tests on a sample of (34) teachers, divided into two groups, a control group (17) female teachers, and an experimental group (17) female teachers. The study tools were the technical enlightenment test and the measure of attitudes toward mobile learning. The study results showed that there were statistically significant differences between the mean scores of the experimental group and the control group in the post-measurement for each of the technical enlightenment test and the measure of attitudes toward mobile learning in favor of the experimental group. The results also showed that there are statistically significant differences between the mean scores of the experimental group teachers in the pre and post measurement of each of the technical enlightenment test and the measure of attitudes toward mobile learning in favor of the post-measurement. The results also showed a lack of statistically significant differences between the mean scores of the experimental group teachers in the attitudes towards the use of mobile learning due to two variables: job position (teacher, senior teacher, expert teacher) grade (prep school, secondary school).

Al-Azzam (2017) conducted a study aimed to measure the use of smart phones in education from educational technology students' points of view in Jordanian private universities. The study adopted the descriptive survey method and used the questionnaire as a tool. The study population was all the students specialized in educational technology in private Jordanian universities. The study sample consisted of (100) questionnaires, each questionnaire consisted of (20) items. The results of the study showed that the extent of the utilization of smart phones was medium, and there was an absence of any statistically significant differences attributable to the study variables (gender, university, and learning stage).

Abdel-Halim and Abdel-Aziz (2018) conducted a study aimed at identifying the challenges and difficulties facing the application of educational technology in primary schools in Algeria from the perspective of teachers (mobile learning as a model). The study followed the descriptive-analytical approach and utilized the interview as a tool. Moreover, the study sample consisted of (30) teachers in primary schools. The results of the study were analyzed using content and content analysis tool, the results showed a weak integration of mobile education in primary schools due to a set of challenges and difficulties, including (self, administrative, technical, material, and security).

Foreign Studies

Baek \& Zhang \& Yun (2017) conducted a study aimed to identify Korean teachers' attitudes toward mobile learning in Turkey, where a Mobile Learning Perception Scale (MLPS) was used by Uzunboylu and Özdaml, on a sample of (140) male and female teachers in primary and secondary schools who were different in terms of (gender, experience, school level, subject). The results of the study showed that the Korean teachers' attitudes toward mobile phone learning in Turkey were low, and the results showed statistically significant differences attributable to the gender variable in favor of female teachers, the variable of the educational level in favor of secondary school male teachers, the variable of experience in favor of those with 15 years or more of experience, and the subject matter variable for languages.

Christensen \& Knezek (2017) conducted a study aimed to identify the openness and readiness towards mobile learning among primary, intermediate, and upper secondary school teachers in the southwestern United States. The study population consisted of (1430) teachers and the study sample consisted of (1414) teachers, and accordingly, upon analyzing the questionnaire, which consisted of four areas (possibilities, benefits, preferences, and external influences), the study found that primary school teachers are more open to using smart phones, tablets, and other mobile devices and information technology devices for mobile learning in the classroom compared to middle and high school teachers.

Ira \& Çolak \& Gecer (2019) performed a study aimed to identify the opinions of high school administrators regarding the employment of mobile technologies in the Izmit district of Kocaeli. The study followed the qualitative research method and used the interview as a tool on an intentional sample of (15) high school administrators. The results of the study showed that high school administrators use mobile learning in their educational practices when they require temporary information, instant communication, and the transfer of audiovisual data used in training courses to the smart board. Likewise, the study showed that employing mobile learning generates positive changes in the educational process, it becomes more effective and efficient, and the audio-visual materials are more active and enjoyable than traditional education.

Dolawattha \& Pramadasa \& Jayaweera (2019) conducted a study aimed to identify the factors affecting university lecturers in mobile learning at the University of Kelaniya, Sri Lanka, where the study followed the descriptive approach and used the questionnaire as a tool on a sample of (60) university lecturers in different academic disciplines. The impact model consisted of six variables (Usefulness, Interactivity, Motivation, Attitude, 
facilitating Conditions, ease of use). Initially, the lecturers were asked to complete a pre-usage questionnaire then they were allowed to use the implemented Moodle mobile application then they were asked to complete the postusage questionnaire. The results of the study showed that the most influencing variable is "Usefulness" as well as a positive impact of mobile learning.

\subsubsection{Comments on previous studies and the subject of this study:}

Reflecting on the previous studies the researcher reviewed, it turns out that these studies have multiplied and varied according to the goals they sought to achieve, the different variables that have been addressed, and the different environments in which they were conducted. Some studies addressed the effect of using mobile learning applications on the development of Technical enlightenment, such as the study of Shams Al-Din (2016), from this study; the researcher took a model for the employment of mobile education in educational situations and its effectiveness. The study of Al-Shahat (2014), in this study, the researcher addressed the challenges and difficulties facing the application of educational technology in schools. The study of Abdel Halim and Abdel Aziz (2018), the researcher chose the issue of factors influencing university lecturers in mobile learning such as Dolayattha \& Pramadasa \& Jayaweera (2019). The previous studies' environments have varied, with Baek \& Zhang \& Yun (2017) in Turkey, the study of Abdel Halim and Abdel Aziz (2018) in Algeria, and the study of Christensen \& Knezek (2017) in the United States of America. Furthermore, this study agreed with the study of Al-Azzam (2017) in Jordan. This study agreed with the previous studies in terms of the approach, the descriptive approach, and in terms of the tool, the questionnaire, and the method of selecting the sample such as the study of Solomon (2014), Abu al-Majd (2014). This study differed from other studies like the study of Christensen \& Knezek (2017), the study of Al-Azzam (2017), the study of Ira \& Çolak \& Gecer (2019). In terms of the study population, this study was similar in its selection of the population of teachers with the study of Abdel Halim and Abdel Aziz (2018), the study of Baek \& Zhang \& Yun (2017), and differed from Ira \& Çolak \& Gecer (2019) which was conducted on high school administrators, and Al-Shahat (2014) study which was conducted on school students.

This study has benefited from previous studies in visualizing and enriching the study tool, and what distinguishes this study from previous studies, Arab and foreign, is the study tool, it is distinguished by the study population as it dealt with teachers in Jordanian schools, the teachers are the pillar of the educational process, and it is characterized by the fact that it addressed variables that have not been linked together in previous studies, which are mobile phones and the educational process, and it is one of the first studies that dealt with the degree of employment of cellular learning in the educational process in Jordanian government schools, according to the researcher's knowledge.

\subsubsection{Study Methodology and Procedures:}

The study adopted the descriptive approach as the most appropriate approach to achieve its goals, especially that it is interested in studying the phenomenon as it is, through data collection and analysis, and the presentation and analysis of results and their interpretation, through their relevance to reality.

\subsubsection{The Study Population and simple :}

The study population consisted of all male and female teachers of Mafraq district schools (4500 ) teachers, according to the statistics of the Jordanian Ministry of Education 2018/2019.

A simple random sample representing the population was chosen, a number of (360) male and female teachers were selected according to the gender and educational qualification. Table No. (1) illustrates the distribution of the sample members according to the variables of the study (gender, and educational qualification).

Table (1): Distribution of the study sample according to its variables

\begin{tabular}{|l|l|l|l|}
\hline Variable & Attribute & Repetition & Percentage \\
\hline \multirow{2}{*}{ Degree } & Bachelor degree & 176 & 48.88 \\
\cline { 2 - 4 } & Postgraduate & & 51.12 \\
\hline \multirow{3}{*}{ Gender } & Male & 150 & 41.66 \\
\cline { 2 - 4 } & Female & 210 & 58.34 \\
\hline Total & & 360 & $\% 100$ \\
\hline
\end{tabular}

\subsubsection{The Study Tool:}

The study tool was developed by referring to theoretical literature and previous studies related to the subject of the study such as Al-Azzam study (2017). The tool was designed in the form of a questionnaire which consisted in its initial form of (26) paragraphs, distributed in three domains, namely the (cognition, skill, and evaluation), and the answers were determined by five criteria, which are (always, most of the time, sometimes, a little, rarely).

The extent of employment of mobile learning in the educational process in Jordanian government schools from the perspective of teachers has been analyzed into three levels (low, medium, and high) according to the arithmetic means of the sample responses for each paragraph as follows: 
Category Length $=$ Maximum Substitutes - Minimum Substitutes / Number of Levels

Category Length $=(5-1 / 3)=1.33$

Thus, the boundaries of the three levels are as follows:

The arithmetic mean which is from $(1-2.33)$ has a low employment level.

The arithmetic mean which is from (2.34 - 3.67) has a medium employment level.

The arithmetic mean which is from (3.68 - 5) has a high employment level.

\subsubsection{The Validity of the Study Tool :}

The validity of the study tool was verified by presenting it to ten arbitrators, members of university teaching staff who are experienced and specialized in the disciplines of education and educational administration in Jordanian universities, to express their observations and evaluations on the suitability of the paragraphs of the questionnaire for the study in terms of content and wording, and the improvements were executed according to the observations agreed upon by $80 \%$ of the arbitrators, the questionnaire tool in its form after the arbitration consisted of (20) paragraphs.

\subsubsection{The Reliability of the Study Tool:}

The reliability of the study tool was established by using the Test-Retest on a sample of (20) male and female teachers from the study population, external to the sample of the study, and the reliability of the tool reached $(0.87)$ which is considered acceptable for conducting the study.

\subsection{The Results and Discussion of the Study:}

The results of the study are presented and discussed below

\subsubsection{The results for the first question:}

Results related to the first question: What is the extent of employing mobile learning in the educational process in Jordanian government schools from the teachers' perspective?

To answer this question, arithmetic means and standard deviations for the extent of employment of mobile learning in the educational process in Jordanian government schools were extracted from the teachers' perspective for the domains and the tool as a whole, then for each domain separately, as follows:

Results for the domains and the tool as a whole: Table (2) shows the results related to the domains of employment of mobile learning in the educational process in Jordanian government schools from the teachers' perspective, in descending order according to the arithmetic mean.

Table (2): Arithmetic averages, standard deviations, rank and grade for the study sample estimates of the degree of employing mobile learning in the educational process in Jordanian government schools from the teachers' perspective.

\begin{tabular}{|l|l|l|l|l|l|}
\hline Rank & Number & Fields & Arithmetic Mean & Standard Deviation & Degree \\
\hline 1 & 1 & Cognition & 1.92 & 0.50 & Low \\
\hline 2 & 2 & Skill & 1.82 & 0.41 & Low \\
\hline 3 & 3 & Evaluation & 1.62 & 0.32 & Low \\
\hline & & TOTAL & 1.79 & 0.33 & Low \\
\hline
\end{tabular}

Table (2) shows that the arithmetic means ranged between (1.92 -1.62), where the cognition domain came first with the highest arithmetic mean of (1.92), and a standard deviation of (0.50), and with a low degree, followed by the skill domain with an arithmetic mean of (1.82), and a standard deviation of (0.41), and with a low degree, then followed by the third place for the evaluation domain with an arithmetic average of (1.62), and a standard deviation of (.32), with a low degree, and the arithmetic mean of the tool at the macro level is (1.79) and a standard deviation of (33) and with a low degree.

It is obvious from the results that the extent of employing mobile learning employment in the educational process in Jordanian government schools according to teachers' perspectives appeared in a low degree, and these results are consistent with the study of Abdel Halim and Abdel Aziz (2018), and the study of Baek \& Zhang \& Yun, (2017), but it differs from the study of Al-Azzam (2017), and the cognition domain came first because the main goal of the educational process is to provide students with the necessary knowledge which teachers seek to achieve at the highest levels. The teachers' attitudes towards the students' utilization of the mobile phone are negative. The skill domain came second because, according to the researcher's opinion, teachers lack the required modern technical skills. The evaluation domain came third because teachers are turning away from modern assessment and evaluation methods, and their confidence in assessing and evaluating their students in the more traditional ways such as written tests and exams.

These results are attributed to the presence of a distinct failure to employ mobile learning in the educational process even though this technology has crossed all temporal and spatial barriers, this might be due to the fear and resistance to change, and that most teachers depend on communicating information traditionally.

The arithmetic means and standard deviations for the study sample estimates were calculated on the items of 
each domain separately, they were as follows:

\subsubsection{The First Domain: Cognition}

To answer the paragraphs of the cognition domain, mathematical means, standard deviations, rank, and grade were used for the study sample estimates in descending order, and Table (3) illustrates this.

Table (3) Arithmetic Means, Standard Deviations, Rank and Grade for the Study Sample Estimates for the Paragraphs of the Cognition Domain in Descending Order according to Arithmetic Means

\begin{tabular}{|c|c|c|c|c|c|}
\hline $\begin{array}{l}\text { Ran } \\
\mathrm{k}\end{array}$ & $\begin{array}{l}\text { Serial } \\
\text { Number }\end{array}$ & Item & $\begin{array}{l}\text { Arithmetic } \\
\text { Mean }\end{array}$ & StandardDeviation & Degree \\
\hline 1 & 4 & $\begin{array}{l}\text { A mobile phone is used to access } \\
\text { learning resources such as search } \\
\text { engines and digital libraries }\end{array}$ & 2.34 & 1.09 & $\begin{array}{l}\text { Mediu } \\
\mathrm{m}\end{array}$ \\
\hline 2 & 6 & $\begin{array}{l}\text { Mobile learning contributes to self- } \\
\text { learning among students }\end{array}$ & 2.03 & 0.99 & Low \\
\hline 3 & 2 & $\begin{array}{l}\text { Mobile phone is used for presentations } \\
\text { and educational programs }\end{array}$ & 2.00 & 0.68 & Low \\
\hline 4 & 1 & $\begin{array}{l}\text { The mobile phone is used to browse the } \\
\text { internet to serve the educational process }\end{array}$ & 1.98 & 0.81 & Low \\
\hline 5 & 3 & $\begin{array}{l}\text { The mobile phone is used to take photos } \\
\text { and videos that serve the educational } \\
\text { process }\end{array}$ & 1.91 & 0.86 & Low \\
\hline 6 & 7 & $\begin{array}{l}\text { The teacher provides the courses in the } \\
\text { form of electronic files for students via } \\
\text { mobile phone }\end{array}$ & 1.89 & 0.72 & Low \\
\hline 7 & 5 & Save classes on mobile phone & 1.74 & 0.73 & Low \\
\hline 8 & 8 & $\begin{array}{l}\text { Employing a mobile phone produces } \\
\text { motivation for students }\end{array}$ & 1.51 & 0.55 & Low \\
\hline \multicolumn{3}{|c|}{ Total } & 1.92 & 0.50 & Low \\
\hline
\end{tabular}

Table (3) shows that the arithmetic means for the cognition domain ranged between (1.51 - 2.34), where paragraph (4) which states "the mobile phone is used to access learning resources such as search engines and digital libraries" came first with an arithmetic mean of (2.34), a standard deviation of (1.09), and with a moderate degree, while paragraph (8) stipulated that "cell phone use produces motivation for students" came in the last rank, with an average mean of (1.51), and a standard deviation of (0.55) and a low degree. The mean score for the cognition domain on the macro level was (1.92) with a low degree.

\subsubsection{The Second Domain: Skill}

To answer the paragraphs of the skill domain, arithmetic means, standard deviations, rank, and grade were used for the study sample estimates in descending order, and Table (4) illustrates this.

Table (4) arithmetic means, standard deviations, rank, and grade for the study sample estimates for the skill domain paragraphs arranged in descending order according to the arithmetic mean.

\begin{tabular}{|c|c|c|c|c|c|}
\hline Rank & $\begin{array}{l}\text { Serial } \\
\text { Number }\end{array}$ & Item & $\begin{array}{l}\text { Arithmetic } \\
\text { Mean }\end{array}$ & StandardDeviation & Degree \\
\hline 1 & 12 & $\begin{array}{l}\text { The teacher integrates students into } \\
\text { effective activities that differ from } \\
\text { traditional teaching methods via the } \\
\text { mobile phone }\end{array}$ & 2.17 & 0.93 & Medium \\
\hline 2 & 9 & $\begin{array}{l}\text { Mobile phone use fosters scientific } \\
\text { thinking }\end{array}$ & 2.03 & 0.96 & Low \\
\hline 3 & 11 & $\begin{array}{l}\text { The use of a mobile phone encourages } \\
\text { interaction and positive relations } \\
\text { between the parties to the educational } \\
\text { process }\end{array}$ & 1.78 & 0.67 & Low \\
\hline 4 & 10 & $\begin{array}{l}\text { The teacher trains students in the } \\
\text { necessary life skills via a mobile phone }\end{array}$ & 1.67 & 0.49 & Low \\
\hline 5 & 13 & $\begin{array}{l}\text { The teacher uses the mobile phone to } \\
\text { make groups with students over social } \\
\text { networks }\end{array}$ & 1.47 & 0.56 & Low \\
\hline \multicolumn{3}{|l|}{ Total } & 1.82 & 0.41 & Low \\
\hline
\end{tabular}

Table (4) shows that the arithmetic means for the skill domain ranged between $(1.47-2.17)$, where paragraph 
(12) states that "the teacher integrates students in effective activities that differ from traditional teaching methods via mobile phone" came first with an arithmetic mean of (2.17), a standard deviation of (0.93), and a low degree, while paragraph (13) that reads: "The teacher uses the mobile phone to make groups with students through social networks " came in the last rank and with arithmetic mean of (1.47), a standard deviation of (0.56), and a low degree. The arithmetic mean for the skill domain on the macro level is (1.82), with a low degree. This might be attributed to the prevailing traditional education practices among teachers due to their interaction with younger school students where they consider these practices as the most appropriate method for all students in the classroom because these teachers lack the required knowledge of modern learning styles like mobile learning.

\subsubsection{The Third Domain: Evaluation}

To answer the paragraphs of the evaluation domain, arithmetic means, standard deviations, rank, and grade were used for the study sample estimates in descending order, and Table (5) illustrates this.

Table (5) Arithmetic means, standard deviations, rank, and grade for the study sample estimates for the evaluation domain paragraphs, arranged in descending order according to the arithmetic mean.

\begin{tabular}{|l|l|l|l|l|l|}
\hline Rank & $\begin{array}{l}\text { Serial } \\
\text { Number }\end{array}$ & Item & $\begin{array}{l}\text { Arithmetic } \\
\text { Mean }\end{array}$ & StandardDeviation & Degree \\
\hline 1 & 16 & $\begin{array}{l}\text { The teacher has the knowledge necessary } \\
\text { to design and develop electronic tests }\end{array}$ & 1.91 & 0.83 & Low \\
\hline 3 & 18 & $\begin{array}{l}\text { The teacher uses modern assessment } \\
\text { methods to measure all aspects of the } \\
\text { educational process. }\end{array}$ & 1.72 & 0.79 & Low \\
\hline 4 & 15 & $\begin{array}{l}\text { The teacher permits sending and } \\
\text { receiving homework and student work } \\
\text { via mobile phone }\end{array}$ & 1.67 & 0.63 & Low \\
\hline 5 & 17 & $\begin{array}{l}\text { The teacher answers students' inquiries } \\
\text { and questions via the mobile phone }\end{array}$ & 1.65 & 0.59 & Low \\
\hline via mobile phone and student groups & $\begin{array}{l}\text { The mobile phone is used to provide } \\
\text { electronic exams }\end{array}$ & 1.51 & 0.53 & Low \\
\hline 7 & 20 & $\begin{array}{l}\text { The mobile phone is used to coordinate } \\
\text { and delay exam dates }\end{array}$ & 1.23 & 0.42 & Low \\
\hline Total & 19 & & 1.62 & 0.32 & Low \\
\hline
\end{tabular}

Table (5) shows that the arithmetic means for the evaluation domain ranged between $(1.23-1.91)$, where paragraph (16) states that "the teacher possesses the necessary knowledge to design and develop electronic tests" came in the first rank with an arithmetic mean of (1.91), a standard deviation of (0.83) and with a low degree, while paragraph (19) reads that "the cell phone is used to coordinate and postpone the dates of the exams" at the last rank, with an arithmetic mean of (1.23), a standard deviation of (0.42), and with a low degree and the arithmetic mean for the evaluation domain on the macro level is (1.62) ), and with a low degree, this might be due to the teachers' conviction that the traditional methods of evaluating students are indispensable because these methods are able to measure and evaluate students and know their achievement level more accurately than electronic tests, and this might be attributed to the fact that teachers lack the conviction of the students ability to self-learn.

\subsubsection{The Results related to the Second Question:}

Results related to the second question that states: Are there any statistically significant differences at the level of $(\alpha=0.05)$ in the study sample estimates for the extent of employment of mobile learning in the educational process in Jordanian government schools according to the gender and educational qualification variables?

\subsubsection{Gender:}

To answer this question, arithmetic means for the authenticity of employing mobile learning in the educational process in Jordanian government schools were extracted according to the gender variable, and Table (6) explains that. 
Table (6) Arithmetic means for the authenticity of employing mobile learning in the educational process in Jordanian government schools according to the gender variable

\begin{tabular}{|c|c|c|c|c|c|}
\hline Domain & Gender & $\begin{array}{l}\text { Arithmetic } \\
\text { Mean }\end{array}$ & $\mathrm{F}$ & $\begin{array}{l}\text { Degrees of } \\
\text { Freedom }\end{array}$ & $\begin{array}{l}\text { Statistical } \\
\text { Significance }\end{array}$ \\
\hline \multirow{2}{*}{ Cognition } & Male & 2.23 & \multirow[t]{2}{*}{84.19} & \multirow{2}{*}{357} & \multirow[t]{2}{*}{0.00} \\
\hline & Female & 1.70 & & & \\
\hline \multirow{2}{*}{ Skill } & Male & 2.07 & \multirow[t]{2}{*}{45.04} & \multirow{2}{*}{357} & \multirow[t]{2}{*}{0.00} \\
\hline & Female & 1.65 & & & \\
\hline \multirow{2}{*}{ Evaluation } & Male & 1.67 & \multirow[t]{2}{*}{5.16} & \multirow{2}{*}{357} & \multirow[t]{2}{*}{0.02} \\
\hline & Female & 1.58 & & & \\
\hline \multirow{2}{*}{ Total marks } & Male & 1.99 & \multirow{2}{*}{2.14} & \multirow{2}{*}{357} & \multirow{2}{*}{0.14} \\
\hline & Female & 1.64 & & & \\
\hline
\end{tabular}

It is clear from the results shown in Table (6) that there are statistically significant differences in the estimates of the study sample individuals for the authenticity of employing mobile learning in the educational process in Jordanian government schools according to the gender variable and are attributed to the male, and on all dimensions and there is none at the total level and this might be attributed to privacy that characterizes the female teachers where the cell phone is used privately more than the male teachers, and it might also be attributed to the free time that the male teachers have more than the female teachers.

\subsubsection{Qualification:}

To answer this question, arithmetic means were extracted for the authenticity of employing mobile learning in the educational process in Jordanian government schools according to the variable of educational qualification, and Table (7) reveals that.

Table (7) Arithmetic Means for the authenticity of employing mobile learning in the educational process in Jordanian government schools according to the variable of educational qualification

\begin{tabular}{|c|c|c|c|c|c|}
\hline Domain & Qualification & Arithmetic Mean & $\mathrm{F}$ & Degrees of Freedom & Statistical Significance \\
\hline \multirow{2}{*}{ Cognition } & Bachelor's degree & 1.80 & \multirow{2}{*}{19.36} & \multirow{2}{*}{358} & \multirow[t]{2}{*}{0.00} \\
\hline & Postgraduate & 2.04 & & & \\
\hline \multirow{2}{*}{ Skill } & Bachelor's degree & 1.64 & \multirow{2}{*}{26.77} & \multirow{2}{*}{358} & \multirow[t]{2}{*}{0.00} \\
\hline & Postgraduate & 2.00 & & & \\
\hline \multirow{2}{*}{ Evaluation } & Bachelor's degree & 1.56 & \multirow{2}{*}{0.32} & \multirow{2}{*}{358} & \multirow[t]{2}{*}{0.57} \\
\hline & Postgraduate & 1.67 & & & \\
\hline \multirow{2}{*}{ Total marks } & Bachelor's degree & 1.67 & \multirow{2}{*}{1.67} & \multirow{2}{*}{358} & \multirow{2}{*}{0.00} \\
\hline & Postgraduate & 1.90 & & & \\
\hline
\end{tabular}

It is apparent from the results shown in Table (7) that there are statistically significant differences in the estimates of the study sample individuals for the authenticity of employing mobile learning in the educational process in Jordanian government schools from the teachers' perspective according to the variable of the educational qualification, and are attributed to higher studies at the macro level of the tool and the cognitive and skill domains. This might be attributed to the fact that postgraduate students are more engaged in educational technology, mobile learning, and distance learning, as they have high skills and employ them in the educational process in schools.

\subsection{Discussion of the Study Results:}

The study found that the extent of employing mobile learning in the educational process in Jordanian public schools from the teachers' perspective was low, which is in line with the study of Abdel Halim and Abdel Aziz (2018), and Baek \& Zhang \& Yun, (2017) but different from the study of Al-Azzam (2017), this might be attributed to the weak interest of teachers and students in e-learning and the greater focus in schools on traditional education, the small number of students using cell phones in schools and its use increases with university students, the lack of confidence of parents in mobile learning, and electronic evaluation, this might be attributed to the weak skills of teachers in employing mobile learning, as it might be due to the lack of suitability of the curricula and infrastructure of schools to mobile learning, it might also be due to limited storage and the possibility of scientific materials loss.

The results showed that there are statistically significant differences according to gender and in favor of the male, and this might be due to the fact that male teachers are more open to communicating with students and parents via mobile phones and other means more than the female teachers because of the female teachers' greater privacy.

The results showed that there are statistically significant differences according to the educational qualification and in favor of postgraduate studies, and this might be attributed to the scientific openness of graduate students and the follow-up of studies and scientific research and their results and recommendations, also this might be attributed to educational scientific research written by postgraduate students related to the educational process, 
and the widespread achieved the technology of education and distance learning. It might be attributed to the ability of graduate students to use their critical thinking abilities properly to solve problems, and self-learn.

\subsection{Recommendations:}

Based on the results of the study, the following recommendations were delivered:

- The Ministry of Education should offer more specialized training courses and workshops in the field of educational technology and mobile learning and urge teachers to utilize them in the educational process.

- Spreading awareness among teachers and students about the advantages of employing mobile learning and modern technology in learning.

- The contribution of the Ministry of Education in employing mobile learning in schools through their policies and procedures.

- Curriculum twinning with mobile learning.

- Including mobile learning and electronic evaluation within the annual plans.

- Educating and training students in critical thinking and self-learning.

- Educating and training teachers on the knowledge necessary to design and develop electronic tests and employ them in the classroom.

- Training teachers on modern evaluation methods to measure all aspects of the educational process through electronic learning methods.

- Teachers should enrich their courses with presentations to strengthen them.

- Conducting more educational research and studies that study the employment of mobile learning in the educational process at universities.

\section{References}

- Abdel Halim, bin Mu'izah and Abdulaziz, bin Abdul Malik (2018). Challenges and Difficulties Facing the Application of Educational Technology in Primary Schools in Algeria from the Perspective of Teachers (Mobile Learning as a Model), Journal of Social and Human Sciences, 7 (14): 3844407

- Abu Al-Majd, Ahmad (2014), the Requirements of Employing E-learning in the Light of the Requirements of Using Information Technology in Pre-university Education Stages, Reading and Knowledge Magazine, Egypt, 154, 163-206.

- $\quad$ Ahmed, Omaima Musa (2011). The Degree of High School Students' Usage in the Northern Jordan Valley of the Internet in the Educational Process and their Attitudes Towards It, unpublished Master Thesis, Yarmouk University, Irbid, Jordan.

- $\quad$ Al-Azam, Feryal Nagy (2017). The Extent of Use of Smart Phones in the Educational Process (a Field Study from the Perspective of Students of Educational Technology in Jordanian Private Universities), unpublished master's thesis, Middle East University, Amman, Jordan.

- $\quad$ Al-Baghdadi, Zaki Abu Nasr (2015), Employing Multimedia Technology in Teaching Arabic by means of Distance Learning, Humanities Journal, Algeria, 43, 63-94.

- Al-Hamid, Ateeq Amal (2013). Students' Use of Mobile Learning Applications in the University Environment, Saida University as a model, unpublished Master Thesis, University of Dr. Taher Moulay Saida, Algeria.

- Al-Omari, Muhammad Abdul Qadir (2011). The Innovations in the Teaching and Learning Process and its Step-by-Step Guide, The World of Modern Books: Jordan.

- $\quad$ Al-Shahat, Suzan Mahmoud (2014). A suggested Model for Employing Mobile Education in Educational Situations and its Effectiveness on Preparatory Middle School Students, unpublished Master Thesis, Ein Shams University, Faculty of Special Education, Egypt.

- $\quad$ Baek,Y\& Zhang,H\& Yun,S.(2017). Teachers' Attitudes toward Mobile Learning in Korea, The Turkish Online Journal of Educational Technology, volume 16 issue 1,PP.154-163.

- Bizan, Hanan Al-Sadiq (2015), Social Media Employment in Community E-Learning, Al-Manhal Magazine, Saudi Arabia, 2 (3), 7-65.

- $\quad$ Christensen, R, \& Knezek, G. (2017), Contrasts In Openness Toward Mobile Learning In The Classroom: A Study Of Elementary, Middle And High School Teachers. 14th International Conference on Cognition and Exploratory Learning in Digital,14, ISBN: 978-989-8533-68-5, 141-148.

- Dolawattha,D,D,M \& Salinda Pramadasa,H,K.(2019), The Impact Model: Teachers' Mobile Learning Adoption in Higher Education. International Journal of Education and Development using Information and Communication Technology (IJEDICT), Vol. 15, Issue 4, pp. 71-88.

- Ira, N., Gecer, A. \& Colak, I. (2019). Detecting the opinions of the secondary school administrators regarding the use of mobile technologies for educational purposes. Educational Policy Analysis and Strategic Research, 14(3), 290-311. doi: 10.29329/epasr.2019.208.13. 
- Sahel, Leila (2014), The Reality of the Educational Process between Old Hammer and Contemporary Anvil, Journal of the Laboratory, Researches in Algerian Language and Literature, University of Biskra, Algeria, (10), 66-86.

- Shams Al-Din, Mona Kamel (2016). The Effect of Using some Mobile Education Applications on Developing the Technical Literacy of Female Economics Teachers and their Atttude towards it. Arab Research in the Fields of Special Education, 4, 353-406. 